\title{
ИСТОЧНИКОВЕДЕНИЕ
}

\section{Рукописи К. Ларионова и К. Малишевского как одни из первых источников изучения буддийских наскальных изображений Тамгалытаса на реке Или}

\author{
Александра Тагировна Баянова ${ }^{1}$, Айса Олеговна Долеева ${ }^{2}$
}

${ }^{1}$ Калмыцкий научный центр РАН (д. 8, ул. им. И. К. Илишкина, 358000 Элиста, Российская Федерация)

заведующая Научной библиотекой и архивом им. П. Э. Алексеевой

iD 0000-0001-7718-802X. E-mail: ale-bayanova@yandex.ru
${ }^{2}$ Калмыцкий научный центр РАН (д. 8, ул. им. И. К. Илишкина, 358000 Элиста, Рос- сийская Федерация).
младший научный сотрудник
(iD) 0000-0002-5077-2821. E-mail: aisasarpa10@mail.ru

\author{
(c) КалмНЦ РАН, 2020 \\ (C) Баянова А. Т., Долеева А. О., 2020
}

\begin{abstract}
Аннотация. Введение. Статья посвящена исследованию уникального буддийского культурного комплекса «Тамгалытас», расположенного в долине реки Или, на правом ее берегу, недалеко от местности Капчагай в Казахстане (ныне - Талгарский район Алматинской области). Наскальные надписи и рисунки Тамгалытаса являются объектом научного изучения уже в течение полутора веков с момента первого его посещения известным казахским ученым, этнографом и путешественником Ч. Ч. Валихановым. Цель статьи - введение в научный оборот ранее не издававшихся рукописных работ военного топографа К. Ларионова и ориенталиста К. Малишевского. Результат: дан анализ историографии изучения памятника, впервые опубликованы собственно рукописи К. Ларионова и К. Малишевского со всеми рисунками, сопровождающими данные документы. Дана оценка рукописей как первых источников по изучению самобытного памятника, свидетельствующего о распространении ламаизма в данном регионе в период джунгарского владычества.
\end{abstract}

Ключевые слова: наскальный рисунок, буддизм, рукопись, ойратское письмо, ойраты, калмыки, Тамгалытас

Благодарность. Исследование проведено в рамках государственной субсидии проект «Устное и письменное наследие монголоязычных народов России, Монголии и Китая: трансграничные традиции и взаимодействия» (№ госрегистрации: АААA-A19-119090590086-0).

Для цитирования: Баянова А. Т., Долеева А. О. Рукописи К. Ларионова и К. Малишевского как одни из первых источников изучения буддийских наскальных изображений Тамгалытаса на реке Или // Монголоведение. 2020. № 1. C. 72-89. DOI: 10.22162/2500-1523-2020-1-72-89. 


\title{
Buddhist Petroglyphs of Tamgaly Tas (Ili River Valley): K. Larionov and K. Malishevsky's Manuscript Reports as Earliest Research Sources
}

\author{
Alexandra T. Bayanova1, Aisa O. Doleeva² \\ ${ }^{1}$ Kalmyk Scientific Center of the RAS (8, Ilishkin St., Elista 358000, Russian Federation) \\ Head of the Alekseeva Scientific Library and Archive \\ iD 0000-0001-7718-802X. E-mail: ale-bayanova@yandex.ru
}
${ }^{2}$ Kalmyk Scientific Center of the RAS (8, Ilishkin St., Elista 358000, Russian Federation) Junior Research Associate
iD 0000-0002-5077-2821. E-mail: aisasarpa10@mail.ru

(C) KalmSC RAS, 2020

(C) Bayanova A. T., Doleeva A. O., 2020

\begin{abstract}
Introduction. The paper deals with the unique Buddhist culture complex of Tamgaly Tas located in the Ili River Valley, in the vicinity of Kapchagay (present-day Talgar District of Almaty Region). The carvings of pictures and inscriptions have been investigated for over a century and a half since the locality was visited by the renown Kazakh scholar, ethnographer and traveler Sh. Walikhanov. Goals. The work introduces into scientific discourse manuscript reports by the military topographer K. Larionov and Orientalist K. Malishevsky. Results. The article analyzes the research historiography, publishes original manuscripts supplemented with all drawings made by the authors, and evaluates them as sources for further studies of the unique monument attesting to the dissemination of Buddhism across the region during the Dzungar rule.
\end{abstract}

Keywords: petroglyph, Buddhism, manuscript, Oirat script, Oirats, Kalmyks, Tamgaly Tas Acknowledgements: The reported study was funded by government subsidy — project name 'Oral and Written Heritage of Mongolic Peoples of Russia, Mongolia and China: Cross-Border Traditions and Interactions' (state reg. no. AAAA-A19-119011490036-1).

For citation: Bayanova A. T., Doleeva A. O. Buddhist Petroglyphs of Tamgaly Tas (Ili River Valley): K. Larionov and K. Malishevsky's Manuscript Reports as Earliest Research Sources. Mongolian Studies. 2020. No. 1. Pp. 72-89. DOI: 10.22162/2500-1523-2020-1-72-89.

\section{Введение}

Святилище Тамгалытас, расположенное на правом берегу реки Или в Казахстане, является одним из известных памятников буддизма. Наскальные изображения буддийских божеств и молитвенных текстов Тамгалытаса являются предметом изучения с XIX в. Существуют различные версии появления наскальных надписей и рисунков в Тамгалытасе. По одной из версий здесь проходили торговые пути Семиречья, по которым буддийские миссионеры направлялись в Среднюю Азию. Существует красивая легенда о том, что одна из миссий буддистов остановилась на живописном берегу реки на отдых. В этот время случилось землетрясение, и рядом с ними рухнула огромная каменная глыба. Путники решили, что это знак свыше, и прекратили свое дальнейшее 

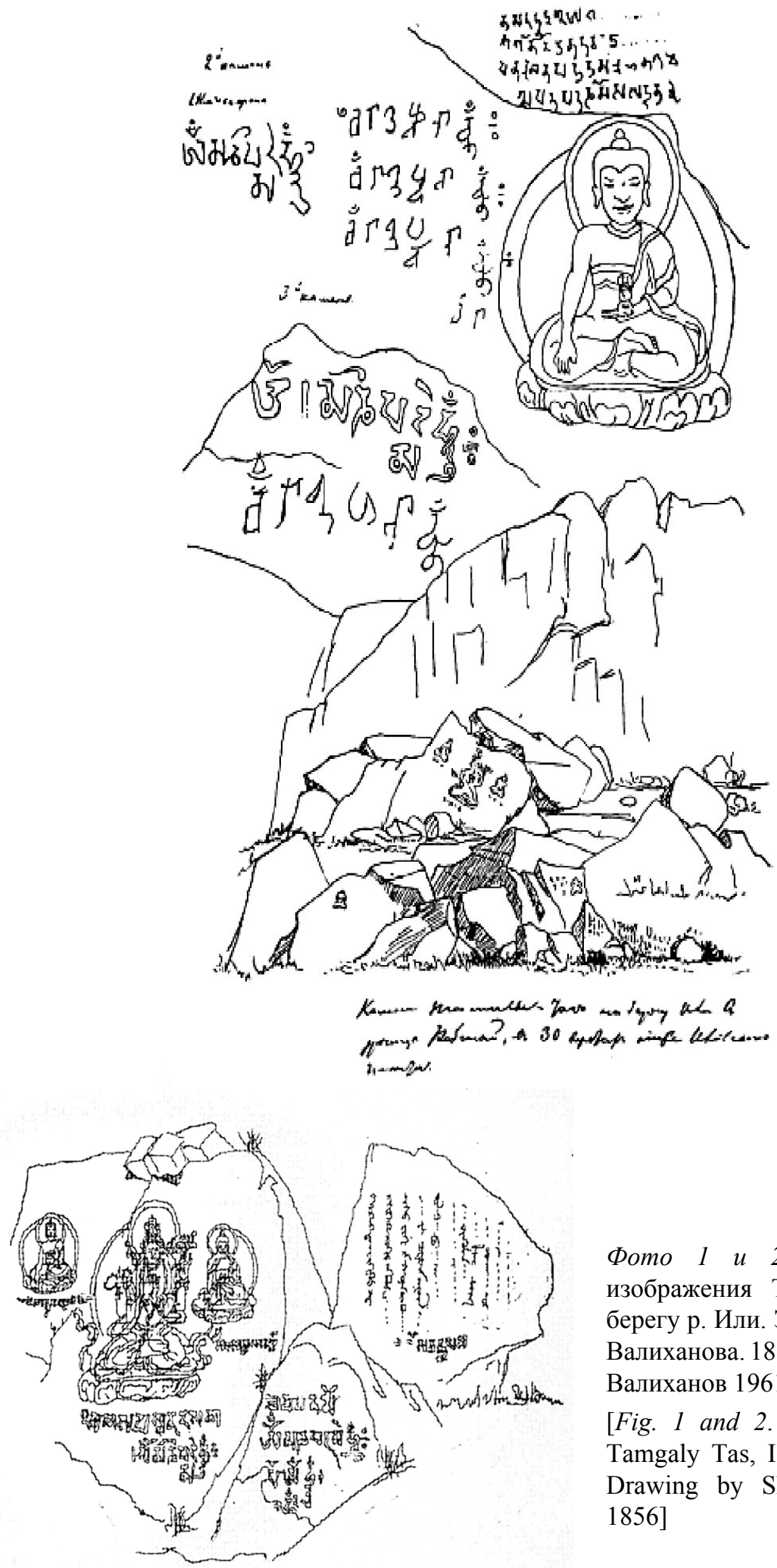

Фото $1 u$ 2. Наскальные изображения Тамгалытас на берегу р. Или. Зарисовка Ч. Ч. Валиханова. 1856 г. [источник: Валиханов 1961б: 407-408].

[Fig. 1 and 2. Petroglyphs of Tamgaly Tas, Ili River Valley. Drawing by Sh. Walikhanov. 1856] 


\section{Источниковедение}

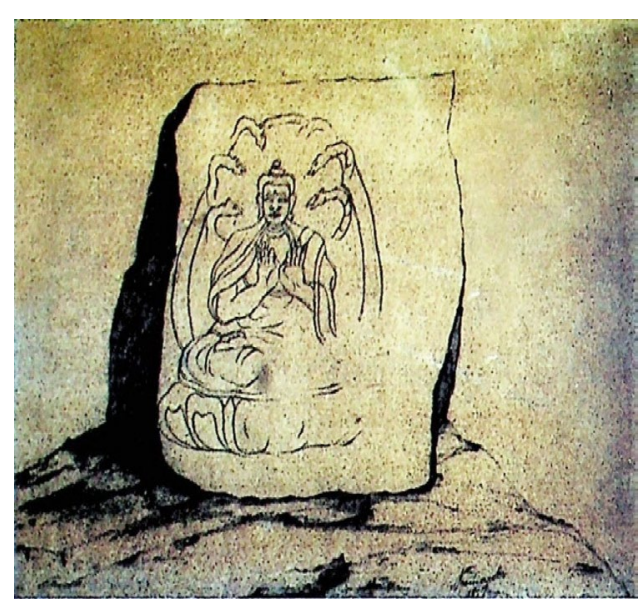

Фото 3. Наскальное изображение Будды Нагешварараджи. Рис. П. М. Кошарова. 1857 г. [источник: Григорьев, Железняков 2010: рис. 3].

[Fig. 3. Petroglyph depicting Nageshvara Raja Buddha. Drawing by P. Kosharov. 1857]

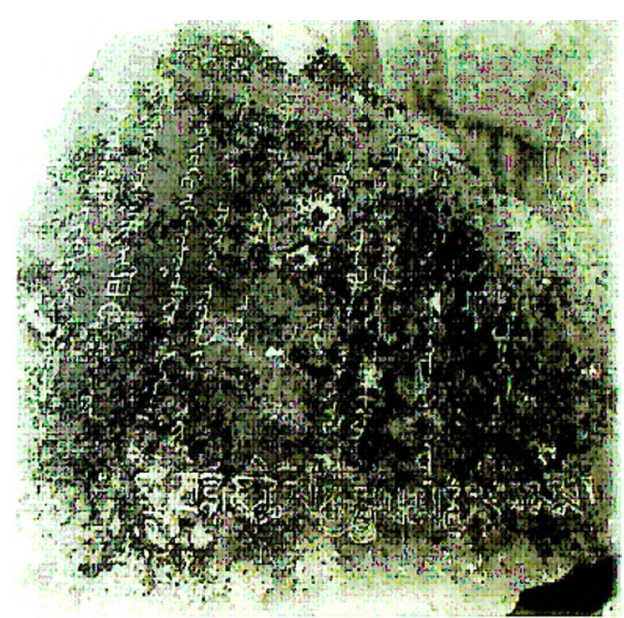

Фото 4. Ойратские и тибетские надписи на камнях Тамгалытаса. Фото Н. Н. Пантусова. 1897 г. [Григорьев, Железняков 2010: рис. 8]

[Fig. 4. Oirat and Tibetan inscriptions of Tamgaly Tas. Photo by N. Pantusov. 1897]

путешествие. На отколовшемся куске камня они высекли изображения трех божеств. ${ }^{1}$

Более правдоподобной считается версия о том, что наскальные изображения сделаны ойратами, что подтверждается тем, что многие надписи сделаны на ойратской письменности «тодо бичиг» ('ясном письме'). ${ }^{2}$

\section{Основная часть}

Впервые этот культурный объект был исследован Ч. Ч. Валихановым, который предпринял поездку в долину реки Или в 1856 г. Свои впечатления о поездке в Тамгалытас Ч. Ч. Валиханов описал в дневниковых записях, но в них нет упоминания о буддийском памятнике: «...поехали на Тамгалыяр ${ }^{3}$. День был жарок (как обыкновенно бывает здесь всегда). Проездив целый день, измучился донельзя» [Валиханов 1961а: 280]. Тем не менее Ч. Ч. Валихановым были сделаны первые зарисовки каменных памятников Тамгалытаса.

Годом позже здесь побывали путешественник П. П. Семенов-Тян-Шанский и художник П. М. Кошаров. Ими также были сделаны зарисовки памятника. К сожалению, первые исследователи Тамгалытаса не посчитали важным подробно описать каменные надписи буддийского святилища, не придав значения открытию. Полноценное изучение памятника ими не было произведено, посещение этой местности ограничилось краткими его описаниями и зарисовками [Рогожинский 2010: 475].

Начало изучению данного памятника было положено К. А. Ларионовым и К. Малишевским. Впервые в 1876 г. военный топограф капитан К. А. Ларионов

\footnotetext{
1 Наскальные изображения Тамгалы и Тамгалы-Тас [электронный ресурc]. URL: https:// worldrockart.ru/risunki/petroglify-tamgaly (дата обращения: 05.01.2020).

${ }^{2}$ Там же.

${ }^{3}$ Тамгальяр - один из вариантов названия Тамгалытас. Существуют несколько вариантов написания названия данной местности: Тамгал-таш, Тамгалы-таш, Тамгалы-тас. В данной публикации мы используем современное написание местности Тамгалытас.
} 


\section{Монголоведение • Mongolian Studies • $2020 \bullet$ T. 12 • №1}

по поручению военного губернатора Семиреченской области Г. А. Колпаковского (1819-1896) проводил геодезические работы и топографическую съемку в долине реки Или. По итогам работ в 1877 г. он написал отчет, который был представлен на IV Археологическом съезде в Казани и является первым подробным и официальным упоминанием памятника. Отчет содержал как ценные сведения в целом о памятнике, так и отдельные подробности: план маршрута, описание дороги к памятнику. Текст отчета был дополнен рисунками, сделанными К. А. Ларионовым [Ларионов 1876].

А. Е. Рогожинский считает, что рукопись К. А. Ларионова имеет «наибольшую ценность как источник того времени» и является «первым подробным описанием памятника» [Рогожинский 2010: 476].

К сожалению, весьма ценные отчеты К. А. Ларионова и К. Малишевского не были нигде опубликованы и были преданы забвению. Рукописи этих отчетов мы обнаружили в рукописном отделе Научной библиотеки им. Н. И. Лобачевского Казанского федерального университета. Считаем необходимым публикацию данных работ, так как они имеют большое значение и могут послужить импульсом к дальнейшему изучению комплекса «Тамгалытас».

Рукопись К. А. Ларионова состоит из 3 листов текста и 6 рисунков (см. приложение 1). На обложке рукописи в верхней ее части написано «VII Восточные древности». На первом листе текста перед названием работы надпись «Печатать без рисунков» и неразборчивая подпись (Рау... или Гау). Текст написан четким каллиграфическим почерком чернилами черного цвета, рисунки черно-белые. Автор дает описание камней, расположенных вниз по течению реки Или на северо-западе от Выселка ${ }^{4}$ Илийского. На трех камнях памятника, как описывает К. А. Ларионов, изображены лики будд, смотрящие на юго-запад. На самом большом из камней высечены изображения трех бурханов, они нарисованы К. А. Ларионовым пером в 1:20 настоящей величины камня. Высота этого камня, как писал впоследствии Н. Н. Пантусов, составляет «73/4 аршина, ширина его по диагонали от головы левого бурхана донизу письмен 41/2 сажени» [Пантусов 1899: 275]. На рисунке надпись, написанная карандашом другим почерком: «Падмани... (далее неразбочиво), покровитель Тибета». На рисунке изображены три отдельные фигуры, сидящие на облаках. В центре - Авалокитешвара (тиб. Ченрезиг), по размеру изображение отличается от двух других, оно более крупное $(3,46 x 3,79$ м - [Григорьев, Железняков 2010: 442]), божество изображено с четырьмя руками: передняя пара рук приложена к груди для молитвы, две другие приподняты, в правой руке - четки, в левой — цветок лотоса.

Авалокитешвара является одним из наиболее почитаемых божеств в буддийском пантеоне. Под изображением божества высечена надпись: «Поклоняюсь святому Ченрезигу». Расположенные по обе стороны от центральной фигуры два образа размером меньше: справа - Будда Шакъямуни (изображение размером 1,42х1,44 м), держащий чашу для подаяний, слева - Манла (изображение размером 1,79x1,46 м), божество врачевания. Под изображениями этих божеств высечены надписи: «Поклоняюсь Будде Шакъямуни», «Поклоняюсь Будде Манла» [Григорьев, Железняков 2010: 443].

В этом же 1877 г. предпринял поездку в долину реки Или и посетил Тамгалытас и ориенталист К. Малишевский. По результатам своей экспедиции он

${ }^{4}$ Так (с прописной буквы) в источнике. 


\section{Источниковедение}

написал отчет, с которым должен был выступить на IV Археологическом съезде в Казани. В рукописи К. Малишевского [Малишевский 1877] есть сопроводительное письмо, адресованное Туркестанским генерал-губернатором К. фон Кауфманом (1818-1882) попечителю Казанского учебного округа П. Д. Шестакову (1826-1889), в котором он направляет письмо К. Малишевского с просьбой о содействии направления данного отчета на съезд [Малишевский 1877: Л. 1].

Рукопись К. Малишевского состоит из 9 листов (см. Приложение 2). Отчет представляет собой описание наскальных изображений Тамгалытаса. По его предположению, надписи являются переводом с санскритского на тангутский язык священных буддийских книг, причем часть этих письмен он пытался разобрать. На нескольких камнях он сразу определил мантру «ом-ма-ни-пад-мехум». На одном из камней К. Малишевский обнаружил надписи на ойратском «ясном письме». К сожалению, не известно, был ли этот отчет представлен IV Археологическому съезду в Казани, также неизвестно, были ли с ним ознакомлены исследователи - об этой работе мы не нашли никаких упоминаний, отсутствуют и ссылки на нее в исследованиях по Тамгалытасу.

Через 30 лет после посещения Тамгалытаса К. А. Ларионовым и К. Малишевским начинается собственно изучение буддийского святилища. В 1897 г. востоковед, этнограф и археолог, член Императорского Русского археологического общества Н. Н. Пантусов (1849-1909) по заданию Императорской Археологической комиссии совершил поездку в урочище Капчагай с целью изучения памятника Тамгалытас, взяв себе в попутчики переводчика, губернского секретаря Г. Л. Асанова и двух проводников из ближайшего аула. В ходе поездки он произвел фотофиксацию памятника, сделал его описание. Тридцать четыре фотоснимка, по которым можно судить «о плане расположения памятников, расстояния между ними и приблизительных размерах общей площади, занимаемой ими» [Пантусов 1899: 276], а также подробный отчет были переданы им в Императорскую Археологическую комиссию. Н. Н. Пантусов определил породу камней («из порфиров и красных песчаников»), направление лицевых сторон изображений (юг и юго-запад), количество («всех камней с более или менее сохранившимися знаками (тамга) нами найдено восемнадцать» [Пантусов 1899: 275]). В своем отчете он отмечал, что на камнях есть рисунки («на самом большом из этих камней высечены три изображения бурханов» и ниже «... есть еще два отдельных камня с одноличными изображениями бурханов» [Пантусов 1899: 275] и надписи («на семи отдельных камнях крупные и мелкие калмыцкие и тибетские надписи» [Пантусов 1899: 275]).

Отчет Н. Н. Пантусова имел ценность и благодаря тому, что впервые были сделаны снимки камней с использованием фотоаппарата, что в те годы было большой редкостью. Для более четкого и качественного изображения надписей с целью дальнейшей их расшифровки исследователь применил особую смекалку. Как пишет Н. Н. Пантусов, «изображения этих бурханов довольно выветрились и вышли бы не совсем отчетливо на фотографических снимках, но при фотографировании некоторые были обсыпаны мукой, дабы штрихи вышли яснее» [Пантусов 1899: 275].

Следует отметить, что удачная в научном плане экспедиция Н. Н. Пантусова состоялась благодаря и рукописной работе К. А. Ларионова. В ходе тщательной подготовки одним из пунктов было и ознакомление с отчетом военного топографа. 
Позже фотоматериалы Н. Н. Пантусова были переданы А. М. Позднееву, который расшифровал некоторые надписи и дал подробные комментарии к ним. Он определил, что на камнях изображены божества Арьябала, Шакъямуни, Манла и Лу-ван [Позднеев 1899]. А. М. Позднеев также дает расшифровку тибетских и ойратских надписей на камнях. На одном из камней он идентифицировал написание шестислоговой мантры «Ом-ма-ни-пад-ме-хум»: одну надпись — тибетскими и три — «калмыцкими буквами» [Позднеев 1899: 280]. На других камнях имеются тарни других бодхисаттв и будд: Манджушри (омба-ге, ом-ма-ри-зэ-мам-со-ха, ом-ра-ба-за-на-ди), Шакъямуни (ом-му-ни-муни-ма-ха-му-ни) [Позднеев 1899: 281]. На одном из камней высечен большой текст, который, как пишет А. М. Позднеев, «больше других и пострадал», поэтому он только частично расшифровал текст. По его утверждению, «изображенные на нем десять строк калмыцкого письма содержат в себе, несомненно, молитвенный текст», который обращен к буддам и бодхисаттвам, высеченным на камнях [Позднеев 1899: 282].

Культовый комплекс Тамгалытас является самым крупным буддийским памятником на территории Северо-Западного Семиречья. По утверждению казахского ученого И. В. Ерофеевой, памятник формировался на протяжении почти века - с 1677 по 1771 гг. [Ерофеева 2010: 524]. То, что комплекс является одним из интереснейших памятников буддизма и принадлежит ойратам, является неоспоримым фактом. И. В. Ерофеева, основываясь на данных китайских источников, также приходит к такому выводу и пишет: «В урочище Тамга измученные и обессилевшие волжские калмыки провели не менее 10-12 дней. <..> Оказавшись в те июльские дни, наконец, в относительно безопасной обстановке, калмыки могли в полной мере оценить огромные масштабы понесенных их народом потерь от преследований иноплеменных номадов, от голода и различных болезней, от бескормицы скота и, вместе с тем, - излить свою благодарность божествам за избавление от неминуемой гибели» [Ерофеева 2010: 524].

Следует отметить, что существуют различные гипотезы о времени появления памятника. Н. П. Шастина считает, что наличие надписей на камнях Тамгалытаса на тибетском языке свидетельствует о том, что они появились не ранее VII в., а надписи на ойратском письме датируются периодом после XII в. (цит. по: [Григорьев, Железняков 2010: 445]), но точнее - еще позже, так как известно, что ойратское (старокалмыцкое) «ясное письмо» было создано Зая-пандитой Огторгуйн Далаем в 1648 г.

С. А. Потапов считает, что памятник появился в период перемирия хана Жангира (1629-1652) с джунгарским ханом Эрдени Батуром-хунтайджи [Потапов 2006: 19].

Многие казахские ученые датируют появление памятника серединой XVII - первой половиной XVIII вв. - периодом джунгарского владычества, а именно периодом правления Галдана Бошогту-хана [Ерофеева 2010: 502].

\section{Заключение}

В начале XXI в. казахские ученые стали активно исследовать памятник Тамгалытас. Но началом научного изучения буддийского памятника следует все же считать исследования военного топографа К. А. Ларионова и ориенталиста К. Малишевского. 


\section{Источниковедение}

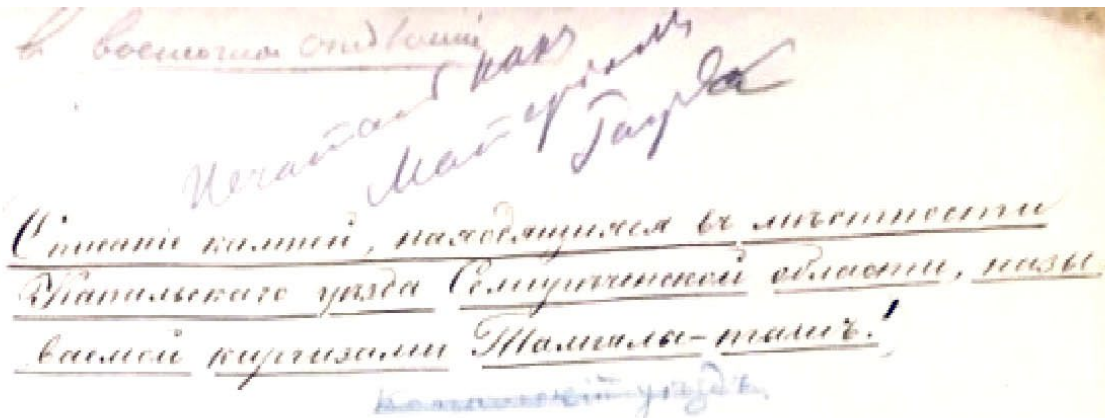

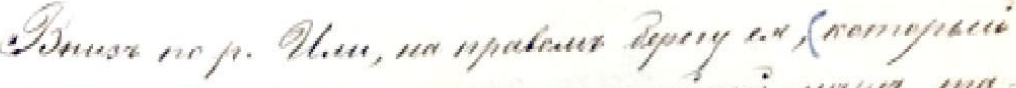

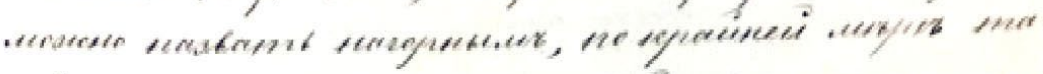

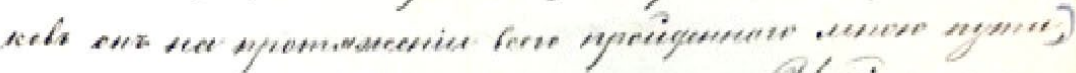

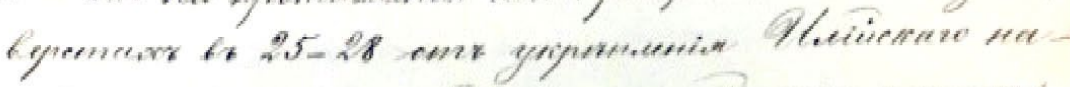

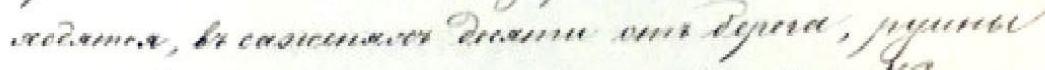

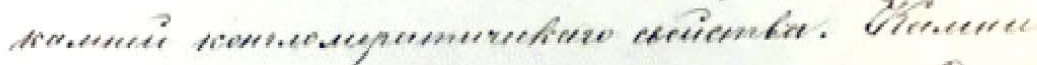

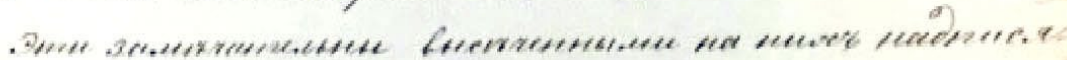

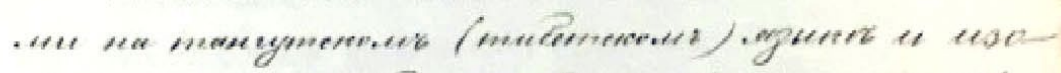

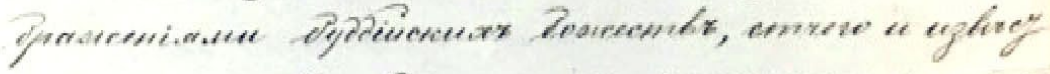

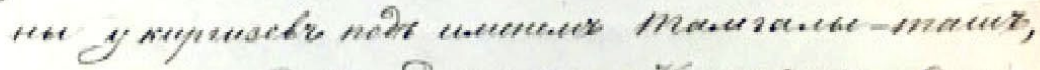

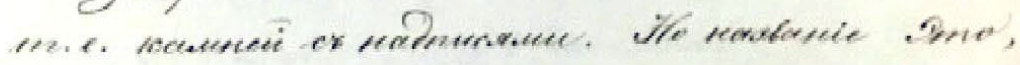

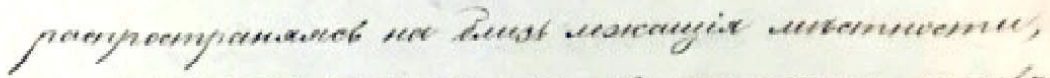

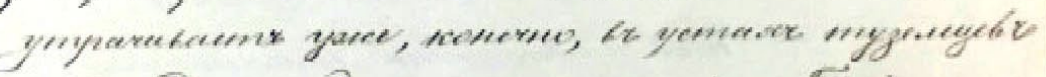

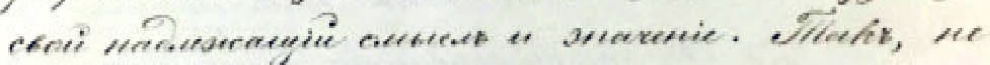

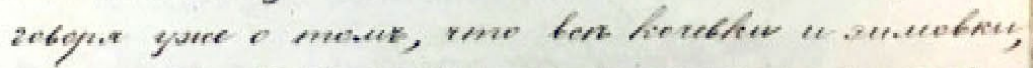

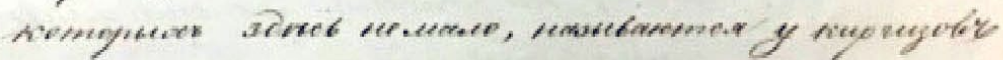

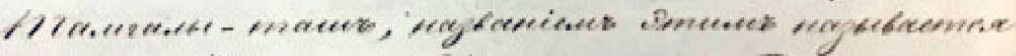

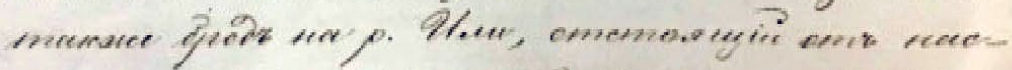

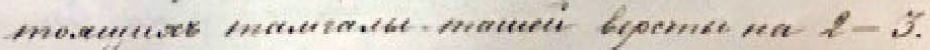

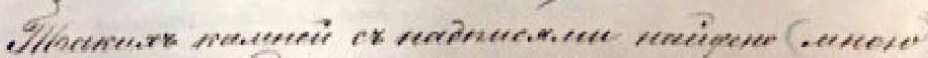

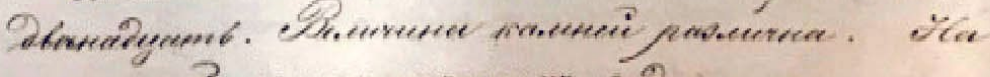

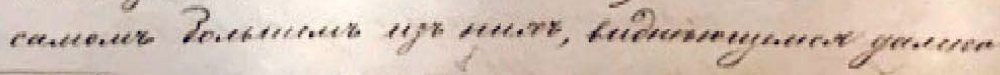

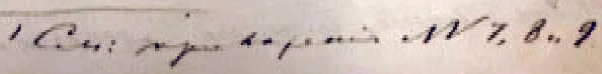

Фото 5. Первая страница работы К. А. Ларионова

[Fig. 5. First page of K. Larionov's report] 


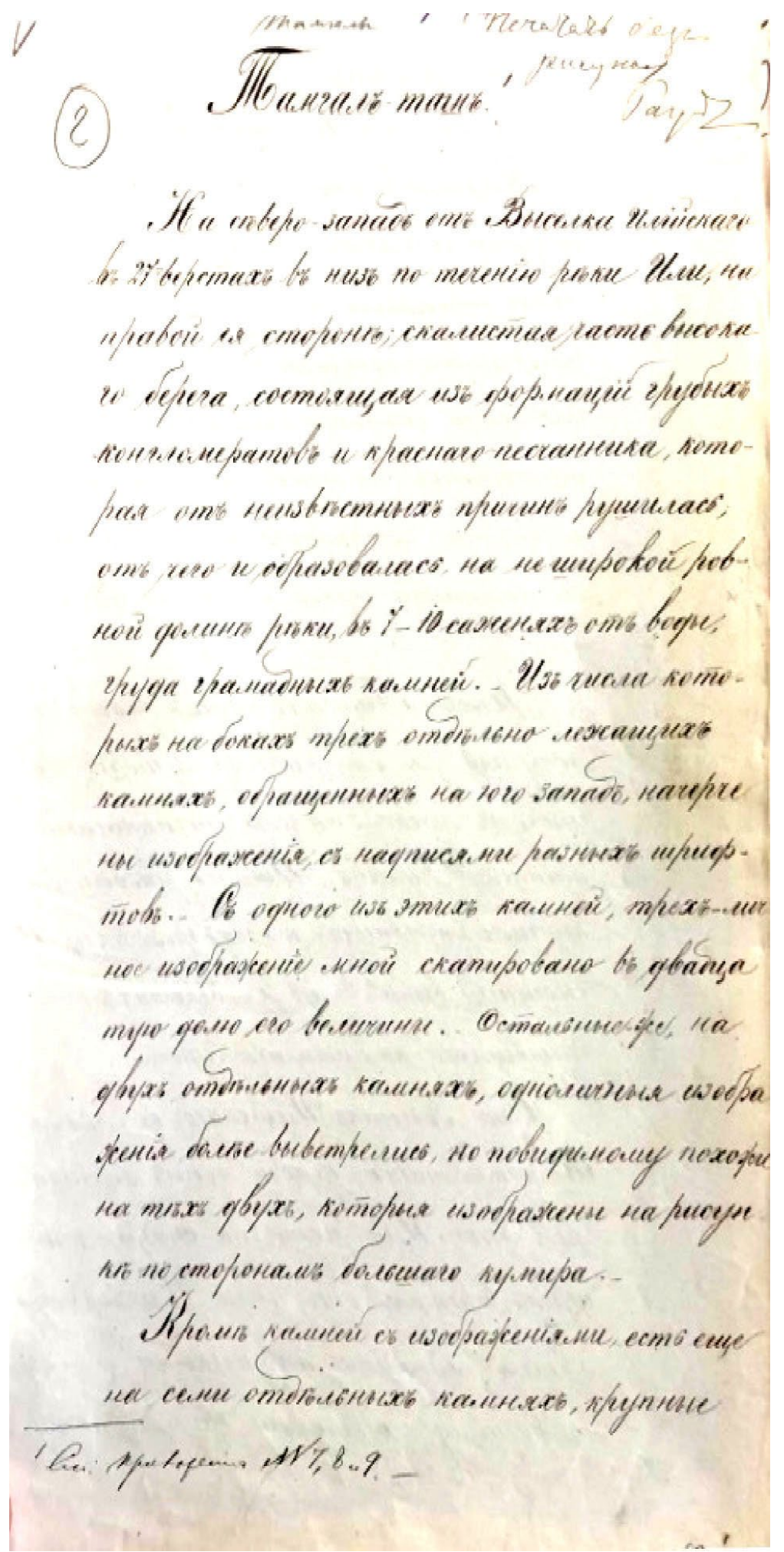

Фото 6. Первая страница работы К. Малишевского

[Fig. 6. First page of K. Malishevsky's report] 


\section{Источниковедение}

\section{Источники}

Ларионов 1876 - Ларионов К. Тамгал-таш. 1876. 9 л., 6 рис., рукопись. Инв. № 1.378 // Рукописный отдел Научной библиотеки им. Н. И. Лобачевского Казанского федерального университета.

Малишевский 1877 - Малишевский К. Описание камней, находящихся в местности Копальского уезда Семиреченской области, называемой киргизами Тамгалы-таш. 1877. 9 л., рукопись. Инв. № 1.429 // Рукописный отдел Научной библиотеки им. Н. И. Лобачевского Казанского федерального университета.

\section{Литература}

Валиханов 1961a - Валиханов Ч. Ч. Дневник поездки на Иссык-Куль // Собрание сочинений в пяти т. Т. 1. Алма-Ата: Изд-во АН КазССР, 1961. С. 228-288.

Валиханов 19616 - Валиханов Ч. Ч. Очерки Джунгарии // Собрание сочинений в пяти т. Т. 1. Алма-Ата: Изд-во АН КазССР, 1961. С. 392-425.

Васильев 1867 - Васильев В. П. О движении магометанства в Китае. СПб.: печатня В. Головина, $1867.30 \mathrm{c}$.

Григорьев, Железняков $2010-$ Григорьев Ф. П., Железняков Б. А. Ламаистское святилище Тамгалытас на реке Или // Роль номадов в формировании культурного наследия Казахстана: мат-лы междунар. науч. конф., посв. памяти Н. Э. Масанова. Алматы: Print-S, 2010. C. 440-458.

Ерофеева 2010 - Ерофеева И. В. История формирования культового комплекса Тамгалытас (1677-1771) // Роль номадов в формировании культурного наследия Казахстана: мат-лы междунар. науч. конф., посв. памяти Н. Э. Масанова. Алматы: Print-S, 2010. C. 490-530.

Нурмухаммедов $1970-$ Нурмухаммедов Н. Искусство Казахстана. М.: Искусство, 1970. $147 \mathrm{c}$.

Пантусов 1899 - Пантусов Н. Тамгалы-тас // Записки Восточного отделения Российского археологического общества (ЗВОРАО). Т. 11. 1897-1898. СПб.: Тип. Имп. Академии наук, 1899. С. 273-276.

Позднеев 1899 - Позднеев А. М. Объяснение надписей и изображений Тамгалы-таса // Записки Восточного отделения Российского археологического общества (3ВОРАО). Т. 11. 1897-1898. СПб.: Тип. Имп. Академии наук, 1899. С. 276-282.

Потапов 2006 - Потапов С. А. Буддийские надписи и петроглифы долины р. Или // Марьяшев А. Н., Потапов С. А. Древности долины реки Или. Алматы: [б. и.], 2006. C. $16-19$.

Рогожинский 2010 - Рогожинский $A$. Е. История изучения и новые исследования культового комплекса Тамгалытас на реке Или // Роль номадов в формировании культурного наследия Казахстана: мат-лы междунар. науч. конф., посв. памяти Н. Э. Масанова. Алматы: Print-S, 2010. C. 474-489.

\section{Sources}

Larionov K. [Tamgal-Tash. 1876]. Manuscript. 9 p., 6 pics. Reg. no. 1.378. At: Kazan Federal University, Lobachevsky Scientific Library, Manuscript Department. (In Russ.)

Malishevsky K. [Description of Stones Situated in a Locality of Kopalsky Uyezd (Semirechye Oblast) Referred to by Native Kirghizes as 'Tamgaly Tash'. 1877]. Manuscript. 9 p. Reg. no. 1.429. At: Kazan Federal University, Lobachevsky Scientific Library, Manuscript Department. (In Russ.)

\section{References}

Erofeeva I. V. Tamgaly Tas culture complex: history of formation, 1677-1771. In: [The Shaping of Kazakhstan's Cultural Heritage: Impacts of Nomadic Populations]. Conf. proc. Almaty: Print-S, 2010. Pp. 490-530. (In Russ.) 
Grigoriev F. P., Zheleznyakov B. A. Lamaist sanctuary of Tamgaly Tas (Ili River Valley). In: [The Shaping of Kazakhstan's Cultural Heritage: Impacts of Nomadic Populations]. Conf. proc. Almaty: Print-S, 2010. Pp. 440-458. (In Russ.)

Nurmukhammedov N. [Arts of Kazakhstan]. Moscow: Iskusstvo, 1970. 147 p. (In Russ.)

Pantusov N. Tamgaly-tas. In: [Eastern Department of the Russian Archaeological Society: (Scholarly) Notes]. Vol. 11: 1897-1898. St. Petersburg: Imperial Academy of Sciences, 1899. Pp. 273-276. (In Russ.)

Potapov S. A. Ili River Valley: Buddhist inscriptions and petroglyphs. In: Maryashev A. N., Potapov S. A. [Antiquities of the Ili River Valley]. Almaty, 2006. Pp. 16-19. (In Russ.)

Pozdneev A. M. Interpreting inscriptions and pictures of Tamgaly Tas. In: [Eastern Department of the Russian Archaeological Society: (Scholarly) Notes]. Vol. 11: 1897-1898. St. Petersburg: Imperial Academy of Sciences, 1899. Pp. 276-282. (In Russ.)

Rogozhinskiy A. E. Tamgaly Tas culture complex: history and research and contemporary studies. In: [The Shaping of Kazakhstan's Cultural Heritage: Impacts of Nomadic Populations]. Conf. proc. Almaty: Print-S, 2010. Pp. 474-489. (In Russ.)

Vasiliev V. P. [China's Mohammedan Movement Revisited]. St. Petersburg: V. Golovin, 1867. 30 p. (In Russ.)

Walikhanov Sh. Sh. Essays on Dzungaria. In: [Collected Works]. In 5 vols. Vol. 1. Alma-Ata: Kazakh SSR Academy of Sciences, 1961. Pp. 392-425. (In Russ.)

Walikhanov Sh. Sh. Journey to Issyk-Kul: travel notes. In: [Collected Works]. In 5 vols. Vol. 1. Alma-Ata: Kazakh SSR Academy of Sciences, 1961. Pp. 228-288. (In Russ.)

Приложение 1

\section{Тамгал-таш}

Л. 1 .

На северо-западе от Выселка Илийского, в 27-ми верстах вниз по течению реки Или, на правой ее стороне, скалистая часть высокого берега, состоящая из формаций грубых конгломератов и красного песчаника, которая от неизвестных причин рушилась, от чего и образовалась на широкой ровной долине реки, в 7-10 саженях от воды, груда громадных камней. Из числа которых на боках трёх отдельно лежащих камнях, обращённых на юго-запад, начерчены изображения с надписями разных шрифтов. С одного из этих камней трёхличное изображение мной скопировано в двадцатую долю его величины. Остальные же на двух отдельных камнях, одноличные изображения более выветрились, но, по-видимому, похожи на тех двух, которые изображены на рисунке по сторонам большого кумира.

Кроме камней с изображениями есть ещё на 7 отдельных камнях крупные Л. 2.

и мелкие разных шрифтов калмыцкие надписи, которые также скопированы ориенталистом К. Малишевским.

Киргизы вблизи этого места теперь кочующие говорят, что они из рассказов своих предков знают только то, что начерченные изображения и надписи на камнях были сделаны калмыками еще до существования на этих местах киргизов, и что эти изображения означают будто бы калмыцкие образа и надписи их молитвы.

Место Тамгал-таш название своё получило уже от киргиз, которое на киргизском языке значит «печатанный» или «писаный камень». Этим названием киргизы называют и брод через реку Или, лежащий выше в двух верстах от молитвенного калмыцкого места. 


\section{Источниковедение}

От Выселка Илийского до места Тамгал-таш дорога после переправы через реку Или идёт на северо-запад в трёх верстах от реки Или: сначала 5 вёрст холмистыми песками, а потом по ровному и твёрдому грунту,

\section{Л. 3.}

приближаясь к берегу реки Или, пройдя этим путем 18 верст, круто поворачивает к реке и, извилисто спустившись в глубокую долину по склону на протяжении двух верст к броду Тамгал-Таш, от которого по долине реки и доходит до места Тамгал-таш.

\section{Капитан Ларионов}

\section{Л. 4.}

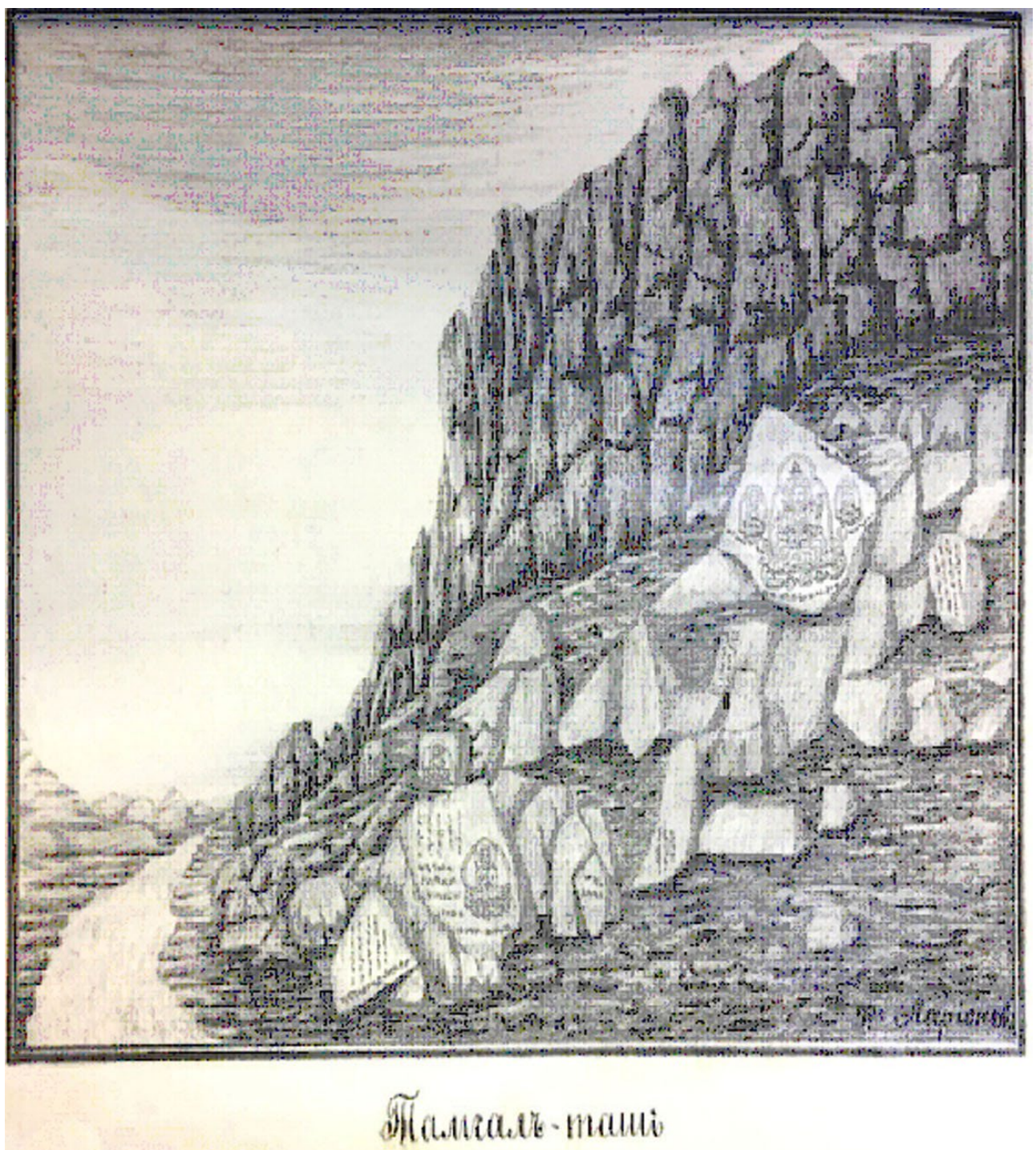

Фото 7. Общий вид

Тамгал-таша

[Fig. 7. Panoramic view of Tamgaly Tas] 
Л. 5 .

$$
\begin{aligned}
& \text { 可产厂可丁 }
\end{aligned}
$$

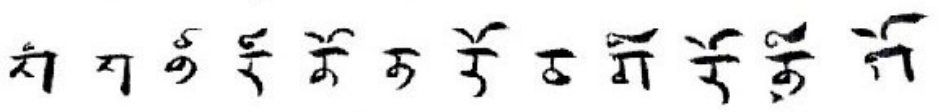

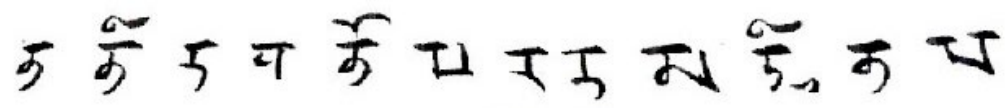

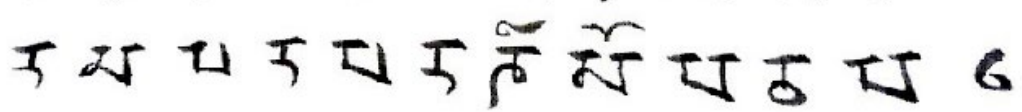

$$
\begin{aligned}
& \text { 车娄 } \\
& \text { 2. } 3
\end{aligned}
$$

Фото 8. Снимок письмен, высеченных на камнях, находящихся в местности

Копальского уезда Семиреченской области, называемой киргизами Тамгалы-таш.

[Fig. 8. Photo of stone inscriptions situated in a locality of Kopalsky Uyezd (Semirechye Oblast) referred to by native Kirghizes as 'Tamgaly Tash']

Л. 6.

Фото 9. Снимок письмен, высеченных на камнях

с тремя изображениями Будды [Fig. 9. Photo of inscriptions carved on stones with three Buddha pictures]

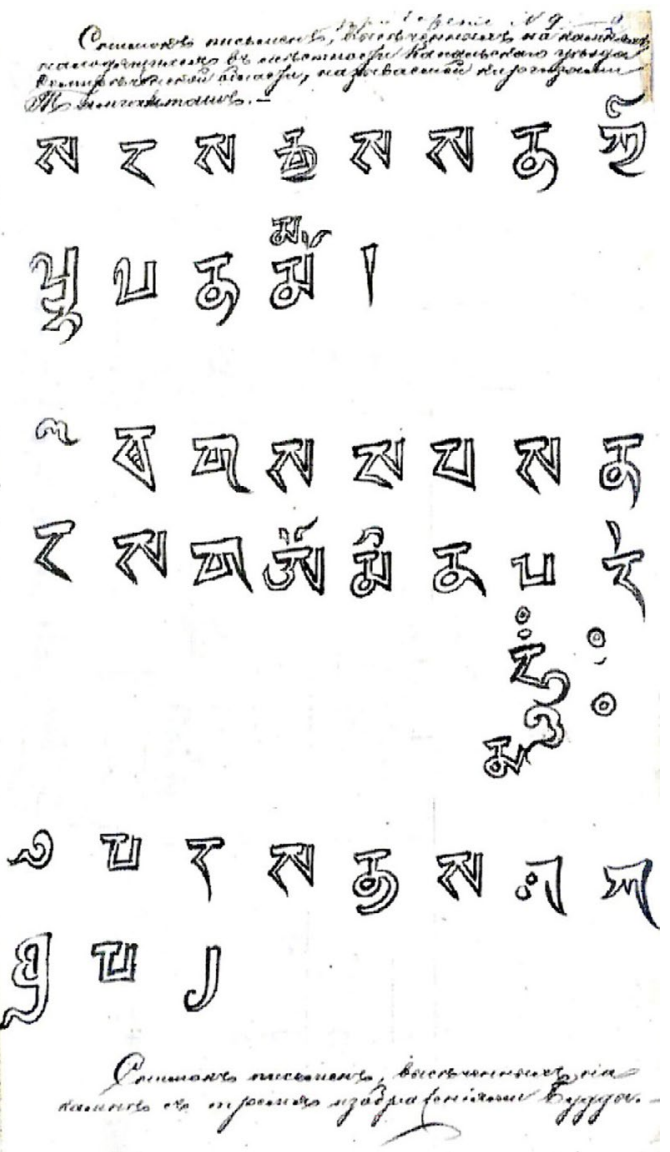




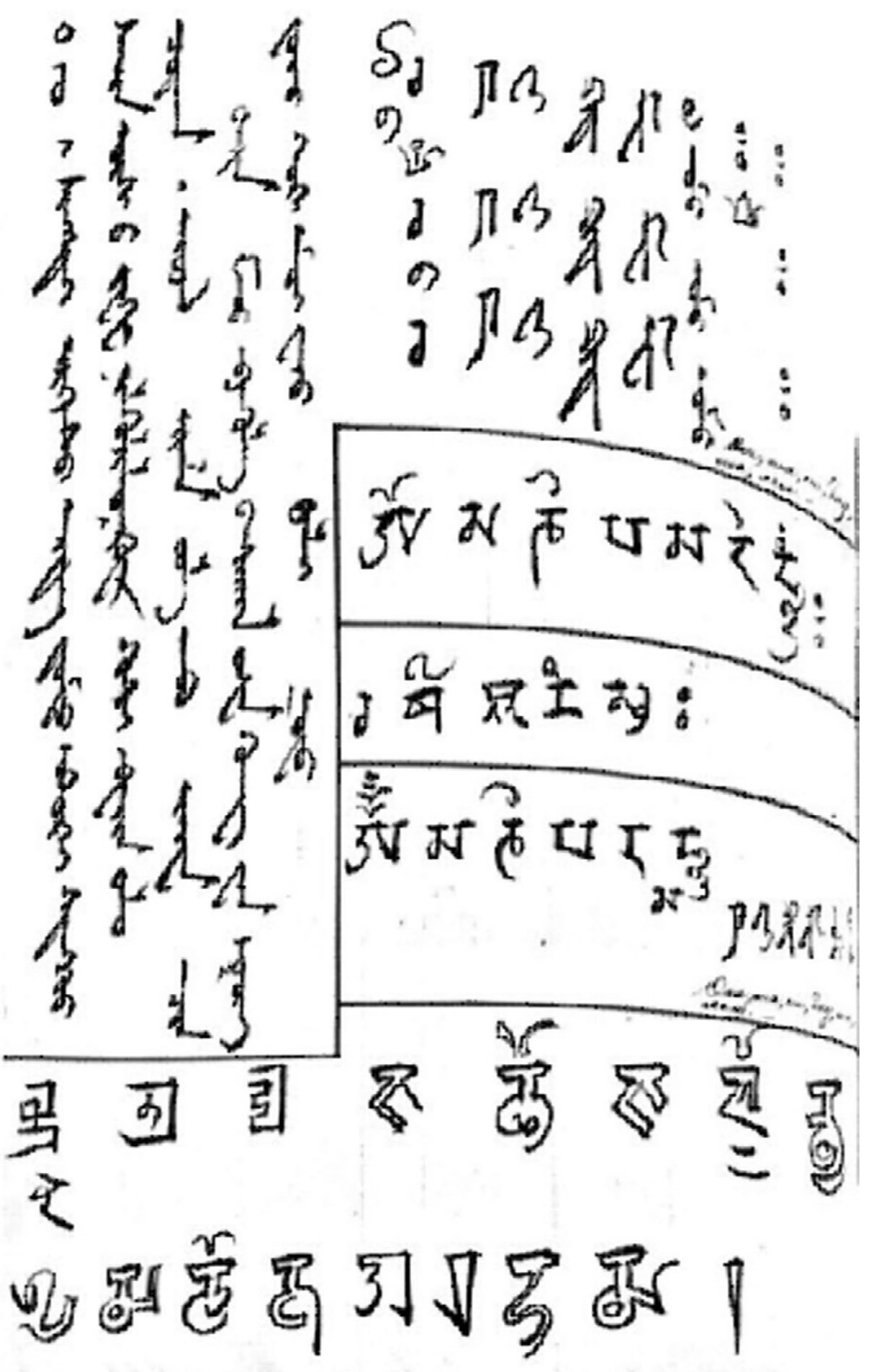

Фото 10. Расшифровка надписей на «тодо бичиг» («ясном письме»)

[Fig. 10. Clear Script (Oirat) interpretation of the inscriptions] 
Л. 8 .

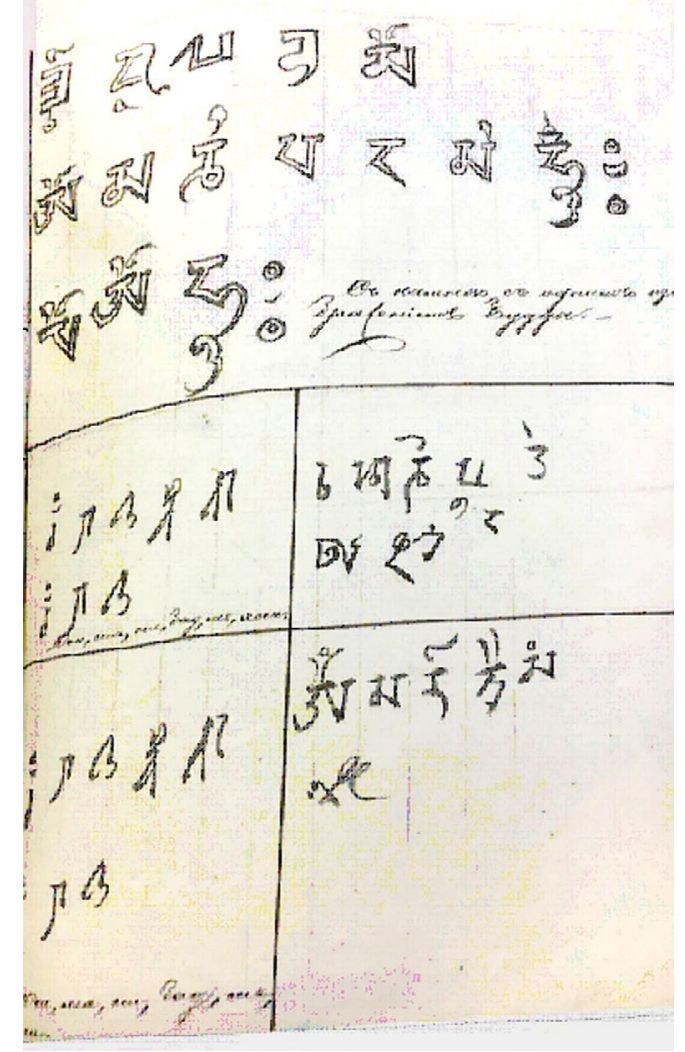

Фото 11. Рукой К. А. Ларионова написано:

«С камней с одним изображением Будды»

[Fig. 11. Written by K. Larionov: 'From stones with one Buddha picture']

Л. 9

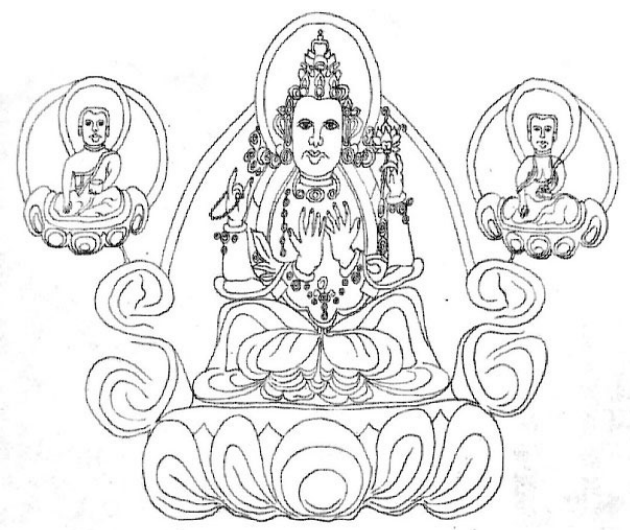

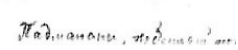

Внизу надпись: «Капитан Ларионов, в двадцатую долю его настоящей величины».

[Fig. 12. One of Tamgaly Tas stones] 


\section{Сопроводительное письмо,} адресованное Туркестанским генерал-губернатором К. фон Кауфманом попечителю Казанского учебного округа П. Д. Шестакову

Л. 1

Милостивый Государь Петр Дмитриевич,

Ваше Превосходительство в начале этого года просили моего содействия к тому, чтобы Туркестанский край принял участие в предстоящем 4-м Археологическом съезде, имеющем быть 31-го июля в Казани.

Сожалею, что настоящее приглашение было сообщено мне довольно поздно. Времени оказалось весьма мало для того, чтобы возможно было представить на предстоящем съезде все археологические богатства

Л. 2

вверенного мне края, и потому пришлось ограничить нашу деятельность для 4-го съезда доставлением ему всех имеющихся в стране сведений о местностях более или менее замечательных в археологическом отношении, и собранных древних монет.

Вследствие сего, имею честь препроводить при сем, согласно прилагаемой описи, доставленные мне описания археологических местностей в Сыр-Дарьинской и Семиреченской областях, с приложением к ним карт, планов, рисунков и монет, которые можно было приобресть до сего времени, с покорнейшею просьбою, если съезд признает эти

Л.3

материалы заслуживающими внимания, поместить их в трудах оного.

С истинным почтением и совершенною преданностью имею честь быть Вашим покорнейшим слугою К. фон Кауфман.

P. S. Только что получил я посылку собранных вещей, старинных документов и карту Ферганской области; предметы эти при особой описи, вместе с сим доставляются.

К. фон Кауфман 17/VI 1877 г.

Л. 4

\section{Описание камней, находящихся в местности Копальского уезда Семиреченской области, называемой киргизами Тамгалы-таш}

Вниз по р. Или, на правом берегу ее (который можно назвать нагорным, по крайней мере, таков он на протяжении всего пройденного мною пути), верстах в 25-28 от укрепления Илийского находятся, в саженях десяти от берега, руины камней конгломератического свойства. Камни эти замечательны высеченными на них надписями на тангутском (тибетском) языке и изображениями буддийских божеств, отчего и известны у киргизов под именем Тамгалы-таш, т. е. камней с надписями. Но название это, распространяясь на близлежащие местности, утрачивает уже, конечно, в устах туземцев свой надлежащий смысл 


\section{Монголоведение • Mongolian Studies • $2020 \bullet$ T. 12 • №1}

и значение. Так, не говоря уже о том, что все кочевки и зимовки, которых здесь немало, называются у киргизов Тамгалы-таш, названием этим называется также брод на р. Или, отстоящий от настоящих тамгалы-ташей версты на 2-3.

Таких камней с надписями найдено мною двенадцать. Величина камней различна. На самом большом из них, виднеющемся далеко

Л. 5

с Или, высечены 3 изображения буддийских божеств. Божества эти разноствуют между собою в величине, да еще кое в чем. Самое главное божество о четырех руках, занимает середину камня, имеет в рост при поджатых ногах аршин 5 с лишком. Две руки сложены подобно почти тому, как складывают их католики во время молитвы на груди, две же другие, воздетые кверху на подобие того, как это делают католические ксендзы в местах аффектационных какой-либо молитвы, держат: одна, левая - священный цветок у буддистов, бадма (лотус) называемый, другая, правая - четки. В почтительном отдалении от главного срединного божества расположены симметрично по бокам его два других божества (также с поджатыми ногами), на половину меньше главного и о двух только уже руках. Положение рук у этих божеств согласно с обычными в буддизме аскетическими правилами: одна лежит на бедре, другая - на груди и держит чашку. Так обыкновенно изображают буддисты всю нищенствующую братью ордена своего - бикшу, основанного Шакъямуни, или по монгольской

Л. 6

транскрипции Шигемуни, современником, по профессору Васильеву ${ }^{5}$, Александра Македонского.

Кроме писанных мною божеств есть еще божества на двух камнях, по одному на каждом; божества эти в своем изображении ничем не отличаются от изображения бикшу. Впрочем, правда требует сказать, что сильно выветрившиеся многие черты одного из божеств не позволяют с точностью определить, есть ли это бикшу или изображение какого-либо другого божества.

Высеченные на камнях надписи, как я уже выше сказал, принадлежат к тангутским письменам, т. е. к тем самым письменам, которыми написаны все буддийские книги тибетцев, при переводе сими последними таковых книг с санскритского языка. Так как при переводе этом многие места священных книг буддистов, в особенности из отдела молитв, оставлены переводившими их в том виде, в каком они находятся на санскритском

\section{Л. 7}

языке, чтобы тем не лишить силы подлинных слов, проистекших от самого Будды или других святых, то тангутские письмена редкий ученый лама может понимать, хотя и прочтет их.

К такому именно отделу тангутских письмен, т. е. к отделу молитв, должны быть отнесены снятые мною надписи с камней Тамгалы-таша. В этом меня убеждает, во-первых, то, что на многих камнях попадаются одни и те же, совершенно похожие друг на друга письменные знаки. Это уже одно обстоя-

\footnotetext{
${ }^{5}$ Васильев В. П. (1818-1900) - востоковед, основоположник отечественного китаеведения. К. Малишевский ссылается на известную статью В. П. Васильева [Васильев 1867: 25].
} 


\section{Источниковедение}

тельство, в связи с находящимися рядом с этими письменами изображениями буддийских божеств, служит полновесным аргументом в пользу высказанного мною положения, так как в этих письменах - всякий, полагаю, согласится, не может уже быть истории какого-нибудь лица, хотя бы и знаменитого, или сказания, легенды про калмыцкого батыря...

Вторым доказательством, и в то же время самым главным, может служить Л. 8

то, что находящиеся на некоторых камнях надписи мною разобраны. Оказывается, что это известная шестисложная молитва буддистов, очень часто ими повторяемая, вроде нашего «Господи помилуй»: ом, ма, ни, пад, ме, хом.

В заключение должен сказать, что на одном из камней находятся калмыцкие письмена. К сожалению, письмена эти сильно выветрились, но, тем не менее, и снятых мною вполне достаточно для того, чтобы сказать, что они в себе ничего особенного, разумею исторического, не содержат. Такой вывод позволю я себе сделать на следующем основании.

В письменах этих я не отыскал ни одного слова, которое имело бы на калмыцком языке какое-либо известное определенное значение и было бы в то же время переводимо. Стало быть, и эти письмена заключают в себе нечто другое, как только какие-либо таинственные

Л. 9

молитвы из отдела Дарани, взятые с санскритского или тибетского языков и написанные без всякого изменения по-калмыцки.

О том, что такое Дарани, и какое значение имеют эти молитвы у буддистов, я имел уже случай говорить. Сказанное мною вместе с объяснением по поводу молитв, открытых в глиняных бурханах, найденных в 1874 году купцом Копыловым на левом берегу р. Джергалана, в бывшем втором участке Кульджинского района, представлено Генерал-Губернатору при рапорте от 17 июня 1875 года, за №936.

К. Малишевский 